\author{
С.С. Дроздов ${ }^{1}$, Г.В. Пєвцов ${ }^{2}$, А.В. Тристан ${ }^{2}$ \\ ${ }^{1}$ Командування Повітряних Сил Збройних Сил Украӥни, Винниия \\ ${ }^{2}$ Харківський начіональний університет Повітряних Сил ім. І. Кожедуба, Харків
}

\title{
МЕТОДИКА ПРОВЕДЕННЯ ФУНКЦІОНАЛЬНОГО ОБСТЕЖЕННЯ ВІЙСЬКОВОЇ ОРГАНІЗАЦІЙНОЇ СТРУКТУРИ
}

Специфічні фактори діяльності Повітряних Сил Збройних Сил Украӥни вимагають пошуку нових підходів до проектування раціональної організаційно-цтатної структури. Показано, щзо при розробиі принципів і методик проектування найбільш важливим є встановлення порядку розподілу завдань між структурними складовими, їх внеску в досягнення иілей організаџії, а також відповідність штатної чисельності поставленим завданням (функціям). Запропоновано методичний апарат, який дозволяє здійснити наукове обтрунтування основних напрямків як вдосконалення систем управління, так і оптимізаиії військових організаціийнх структур в иілому.

Ключові слова: військова організаційна структура, організаційно-штатна структура, Повітряні Сили Збройних Сил України, функціональне обстеження.

\section{Вступ}

Постановка проблеми. При розробці принципів і методик проектування організаційно-штатних структур важливо відійти від уявлення структури як незмінного набору органів, що відповідають кожній спеціалізованій функції управління. Організаційноштатна структура - поняття багатогранне. Воно насамперед включає систему цілей і їх розподіл між різними підрозділами, оскільки механізм діяльності має бути орієнтованим на досягнення цілей. Сюди ж належить склад підрозділів, які пов'язані певними відносинами: розподіл завдань і функцій по всіх ланках управління, розподіл відповідальності, повноважень і прав усередині організації, що відображає співвідношення централізації й децентралізації управління. Важливими елементами структури управління є комунікації, потоки інформації й документообіг в організації. Нарешті, організаційноштатна структура - це поведінкова система, це люди i їх групи, що постійно вступають у різні взаємини для вирішення спільних завдань.

Така багатосторонність організаційного механізму несумісна з використанням яких-небудь однозначних методів - формальних або неформальних. Саме тому необхідно виходити з комбінації наукових методів і принципів формування структур (системного підходу, програмно-цільового управління, організаційного моделювання) 3 експертно-аналітичною роботою, вивченням вітчизняного й закордонного досвіду, тісною взаємодією науковців і тих, хто практично буде впроваджувати й використовувати проектований організаційний механізм. В основу методології проектування структур має бути покладене чітке формулювання цілей організації.
Питання формування раціональних організаційно-штатних структур є актуальним для різних галузей наукової, виробничої, організаційної діяльності. В умовах трансформації Збройних Сил (3С) України, адаптації їх системи управління до систем управління НАТО, важливим стає завдання проведення функціонального обстеження військових організаційних структур 3 метою визначення розподілу завдань між структурними підрозділами, оцінювання вкладу структурних підрозділів у досягнення цілей організації, відповідність штатної чисельності покладеним завданням.

Слід зауважити, що специфічні фактори діяльності Повітряних Сил (ПС) ЗС України, як, наприклад, організація бойового чергування, управління військами в ході виконання ведення операцій (бойових дій) потребують пошуку нового методичного апарату, який дозволить оцінити структурні підрозділи військової організаційної структури як за виконанням загальних функцій, так і за специфічними завданнями (функціями). Даний методичний апарат необхідний для наукового обгрунтування шляхів як удосконалення системи управління, так і оптимізації військових організаційних структур загалом.

Аналіз останніх досліджень і публікацій. Питанню оптимізації військових організаційних структур та удосконаленню системи управління присвячено достатньо велику кількість публікацій, серед яких потрібно звернути увагу на роботи [1-11].

Так, в роботі [1] сформовані рекомендації щодо дотримання принципу системності при виборі шляхів оптимізації структур органів управління для досягнення мети операції (бойових дій) на суші, у повітрі, на морі. В статті [2] розроблений методичний підхід щодо проектування структури органів управління, в основі якого лежить функціонально-цільовий спосіб, 
який враховує основні вимоги і принципи формування управлінських структур. В роботі [3] розроблена методика визначення раціонального варіанту складної системи військового призначення.

В роботі [4] розроблені методичні підходи до обгрунтування перспективної структури системи управління військами (силами) з урахуванням адаптації іiї до сучасних умов ведення збройної боротьби.

В статті [5] приведена удосконалена сукупність показників якості для обгрунтування структури органів управління системи управління ПС. В статті [6] проведений аналіз вимог до систем управління військами, передового досвіду щодо підходів, шляхів удосконалення автоматизованих систем управління військами та систем управління військами в цілому. В роботі [7] розглянуто підходи до формування системи інформаційного забезпечення системи управління ПС.

В роботах [8-10] наводяться моделі та методи формування раціональних структур, однак вони характерні для цивільного (комерційного) сектору.

В роботі [11] розроблено методичні підходи до раціонального розподілу оборонного бюджету Укра- їни 3 урахуванням потреб та ступеня залучення складових сил оборони до виконання завдань.

В той же час потрібно зробити висновок, що цілісної методики проведення функціонального обстеження військової організаційної структури для вироблення обгрунтованих рекомендацій щодо іiі реформування та розвитку знайдено не було.

Мета статті - розробка методики проведення функціонального обстеження військової організаційної структури для оцінювання відповідності іiї організаційно-штатної структури покладеним на неї завданням як у мирний час, так і в особливий період.

\section{Виклад основного матеріалу}

Під військовими організаційними структурами будемо розуміти органи військового управління, 3'єднання, військові частини (підрозділи), військові навчальні заклади, установи та організації Збройних Сил України [12].

Структура методики проведення функціонального обстеження військової організаційної структури наведена на рис. 1.

\begin{tabular}{|c|}
\hline 1 ЕТАП \\
Закріплення завдань військової організаційної структури за \\
структурннмн підрозділамн
\end{tabular}

Рис. 1. Структура методики

Джерело: розроблено авторами.

Перший етап методики спрямований на оцінювання якості відпрацювання положень про військову організаційну структуру та відповідних положень про іiі структурні підрозділи (управління, відділи, відділення, групи, служби).

Другий етап методики спрямований на оцінювання відповідності чисельності структурних підрозділів (управління, відділи, відділення, групи, служби) покладеним на них завданням (без збільшення чисельності військової організаційної структури).

Третій етап методики спрямований на оцінювання спроможності виконувати завдання військовою організаційною структурою 3 планування та управління військами (частинами, підрозділами).
Вхідними даними методики є:

- положення про військову організаційну структуру;

- положення про структурні підрозділи військової організаційної структури;

- штатна/списочна чисельність військової організаційної структури;

- Наказ Командувача (командира) військової організаційної структури про розподіл особового складу за пунктами управління;

- функціональні обов'язки управлінь (відділів, відділень, груп, служб) в особливий період.

Показниками, які будуть оцінюватися, пропонується обрати: 
- коефіцієнт закріплення завдань військової організаційної структури за структурними підрозділами $\left(K_{33}\right)$;

- коефіцієнт закріплення структурних підрозділів за завданнями $\left(K_{c n}\right)$;

- коефіцієнт відповідності чисельності структурного підрозділу військової організаційної структури навантаженню на підрозділ $\left(K_{b}\right)$;

- коефіцієнт спроможності військової організаційної структури планувати та управляти підпорядкованими військами (частинами, підрозділами) $\left(K_{c}\right)$.

На першому етапі методики всі структурні підрозділи військової організаційної структури повинні бути закріплені за завданнями. Всі завдання військової організаційної структури повинні бути закріплені за структурними підрозділами військової орга- нізаційної структури.

На другому етапі методики для структурних підрозділів, які мають коефіцієнт відповідності чисельності структурного підрозділу військової організаційної структури навантаженню на підрозділ меншим за 0,75 або більшим за 1,25 , визначаються відділи (відділення, групи, служби) за завданнями, які мають недостатнє або надмірне навантаження за функціями управління.

На третьому етапі складається таблиця оцінювання за практичну роботу на пункті управління (під час штабних тренувань, командно-штабних навчань органу військового управління (штабу)).

Оцінювання організаційно-штатної структури військової організаційної структури покладеним на неї завданням здійснюється за критеріями, наведеними в табл. 1.

Таблиця 1

Критерії оцінювання організаційно-штатної структури військової організаційної структури

\begin{tabular}{|c|c|c|c|}
\hline \multirow[t]{2}{*}{ Оцінка } & \multicolumn{3}{|c|}{ ЕТАП } \\
\hline & 1 Етап & 2 Етап & 3 Етап \\
\hline Відповідає & $\begin{array}{l}K_{33}=1 \\
K_{c n}=1\end{array}$ & $\forall K \in[0,75 ; 1]$ & $\begin{array}{l}\text { Спроможний виконувати завдання за } \\
\text { призначенням/ Обмежено спроможний } \\
\text { виконувати завдання за призначенням }\end{array}$ \\
\hline $\begin{array}{l}\text { Частково } \\
\text { відповідає }\end{array}$ & $\begin{array}{l}K_{33}=1 \\
K_{c n}=1\end{array}$ & $K \in[0,75 ; 1] 80 \%$ & $\begin{array}{l}\text { Спроможний виконувати завдання за } \\
\text { призначенням/ Обмежено спроможний } \\
\text { виконувати завдання за призначенням }\end{array}$ \\
\hline Не відповідає & \multicolumn{3}{|c|}{ не виконується на оцінку відповідає (частково відповідає) } \\
\hline
\end{tabular}

Джерело: розроблено авторами.

Розкриємо основні положення кожних етапів.

Перший етап.

1. 3 положення про військову організаційну структуру виписуються іiї завдання, формуючи множину $Z=\left\{z_{1}, z_{2}, \ldots, z_{n}\right\}$, де $n-$ кількість завдань.

2. Формується множина структурних підрозділів військової організаційної структури $P=\left\{p_{1}, p_{2}, \ldots, p_{m}\right\}$, де $m$ - кількість структурних підрозділів.

3. Формується матриця закріплення завдань $A$ розмірності $[m \times n]$, елементами якої є “одиниця”, якщо в положенні про структурний підрозділ є завдання, що відповідає завданню з множини $Z$ структурного підрозділу, та “нуль” в іншому випадку.

Приклад матриці наведено на рис. 2.

\begin{tabular}{|c|c|c|c|c|c|c|}
\hline \multirow{2}{*}{\multicolumn{2}{|c|}{1}} & & \multicolumn{2}{|l|}{ H } & \multirow[b]{2}{*}{ 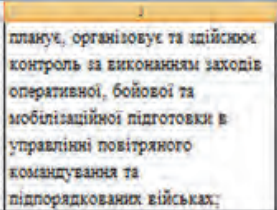 } & \multirow[b]{2}{*}{ 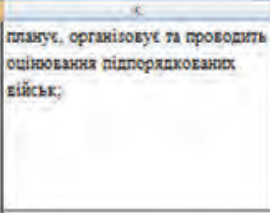 } \\
\hline & & & 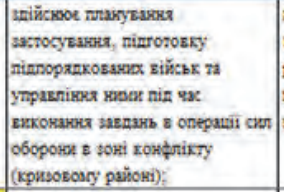 & 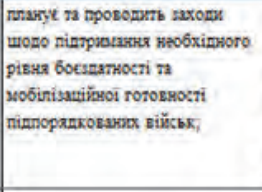 & & \\
\hline$\frac{2}{3}$ & $\omega_{\top}$ & та6 & & & & \\
\hline 4. & 3 & Відділ персоналу & & & & \\
\hline s. & 2 & Мобілізаційна група & & & & \\
\hline 8 & 2 & Організаційно-штатна група & & & & \\
\hline , & + & Група розвідки & & & & \\
\hline a) & 2 & Управління поточних операцій штабу & 1 & & & \\
\hline$\rightarrow$ & $\cdot$ & $\begin{array}{l}\text { Відділ поточних операцій управління } \\
\text { поточних операцій }\end{array}$ & & & & \\
\hline 10 & , & $\begin{array}{l}\text { Відаіл координації та планування вогневого } \\
\text { ураження управління поточних операцій }\end{array}$ & & & & \\
\hline 12 &. & $\begin{array}{l}\text { Група інформаційноі підтримки управління } \\
\text { поточних операцій }\end{array}$ & & & & \\
\hline 12 . & 2 & Відділ логістики штабу & & & & \\
\hline u. & $n$ & $\begin{array}{l}\text { Група планування інфраструктурного } \\
\text { забезпечення відділу логістики }\end{array}$ & & & & \\
\hline 4 & : & Відділ планування застосування штабу & & 1 & 1 & 1 \\
\hline 2 & 12 & Віддіп з8'язку та інформаційних систем & & & & \\
\hline
\end{tabular}

Рис. 2. Приклад матриці закріплення завдань Джерело: розроблено авторами. 
4. Якщо кожен стовпець матриці $A$ має хоча б одну “одиницю”, то вважається, що завдання закріплено за структурним підрозділом і коефіцієнт $K_{33_{i}}=1$, в іншому випадку $K_{33_{i}}=0$. Коефіцієнт $K_{3 з}$ визначається за формулою:

$$
K_{33}=\frac{\sum_{i}^{n} K_{33_{i}}}{n} .
$$

5. Якщо кожен рядок матриці $A$ має хоча б одну “одиницю”, то вважається, що структурний підрозділ має закріплені завдання і коефіцієнт $K_{c n_{i}}=1$, в іншому випадку $K_{c n_{i}}=0$. Коефіцієнт $K_{c n}$ визначається за формулою:

$$
K_{c n}=\frac{\sum_{i}^{m} K_{c n_{i}}}{m}
$$

Другий етап.

Складається перелік завдань військової організаційної структури та проводиться експертний розподіл їх важливості $\left(k_{f}\right)$ за шкалою:

“дуже важлива” (ДВ) (1,00-0,80);

“важлива” (ВЖ) $(0,80-0,64)$;

“середня" (СР) (0,64-0,37);

“низька" (НЗ) $(0,37-0,20)$;

“незначна” (НЧ) $(0,20-0,01)$.

Аналізуючи положення про структурні підрозділи військової організаційної структури, виділяються задачі, сукупне розв'язання яких веде до реалізації завдання управління. Задачам надається такий коефіцієнт, як і завданням, до яких вони відносяться. Кожний структурний підрозділ у відповідності до своїх завдань може приймати участь у реалізації завдань через наступні дії:

“безпосередньо виконує” (В) $(1,00-0,80)$;

“контролює та координує роботу” (К) $(0,8$ $0,64)$;

“надає дані (інформаційно забезпечує)” (I)

(0,64-0,37);

“погоджує” (П) (0,37-0,20);

“обліковує” (О) (0,20-0,01).

Кожній дії надається коефіцієнт $\left(k_{d}\right)$ за аналогом вищенаведеної шкали.

Розраховується абсолютне значення участі $j$-го підрозділу в реалізації завдань управління військової організаційної структури:

$$
K_{a b c}^{(j)}=\sum_{i=1}^{N_{Z}} K_{f}^{(i j)} \cdot K_{d}^{(i j)},
$$

де $K_{f}^{(i j)}$ - важливість завдання, до якого відноситься $i$-та задача $j$-го підрозділу;

$K_{d}^{(i j)}$ - коефіцієнт дії при виконанні $i-і ̈$ задачі j-м підрозділом;

$N_{z}$ - загальна кількість задач.

Розраховується нормоване значення участі підрозділу в реалізації завдань управління військової організаційної структури:

$$
\bar{k}_{a b c}^{(j)}=\frac{\sum_{i=1}^{N_{Z}} k_{f}^{(i j)} \cdot k_{d}^{(i j)}}{\sum_{j=1}^{N_{p}} \sum_{i=1}^{N_{Z}} k_{f}^{(i j)} \cdot k_{d}^{(i j)}},
$$

де $N_{p}$ - загальна кількість структурних підрозділів.

Нормоване значення $\bar{k}_{a b c}^{(j)}$ задовольняє умові:

$$
0<\bar{k}_{a b c}^{(j)}<1
$$

За чисельністю (штатною) визначається частка структурного підрозділу в загальній чисельності військової організаційної структури:

$$
0<k_{\text {sh }}<1 \text {. }
$$

Коефіцієнт відповідності розраховується за формулою:

$$
K_{u j}=\frac{\bar{k}_{a b s}^{(j)}}{k_{s h}} .
$$

Варіант розрахунку наведено на рис. 3 .

За результатами розрахунку формується відповідний графік (рис. 4).

Третій етап.

Оцінювання за практичну роботу на пункті управління під час штабних тренувань, командноштабних навчань органу військового управління (штабу) визначається за трьома критеріями [13] та наведено в табл. 2.

В характеристиках оцінки, наведених в табл. 2, оцінюється саме здатність існуючої організаційної структури сформувати органи управління системи управління військової організаційної структури та функціонувати у відповідності з вимогами керівних документів щодо планування операції (бойових дій) та управління підпорядкованими військами (силами). 


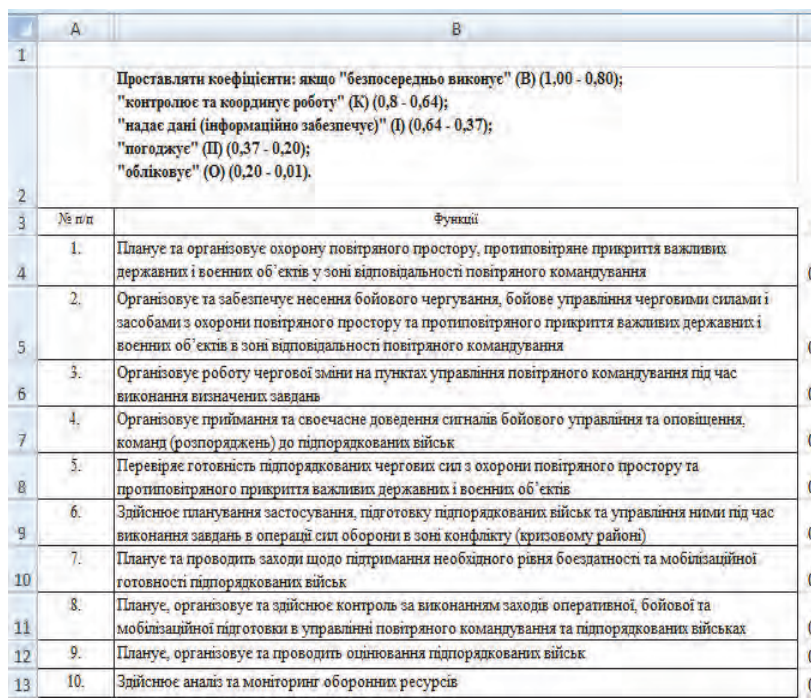

\begin{tabular}{|c|c|c|c|c|c|c|c|c|c|}
\hline \multirow{2}{*}{ 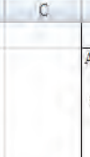 } & \multicolumn{9}{|l|}{ D } \\
\hline & 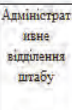 & $\begin{array}{l}\text { Biminin } \\
\text { nepposary }\end{array}$ & \begin{tabular}{|l|l} 
Tpynia \\
possinar
\end{tabular} & 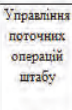 & 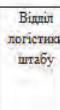 & 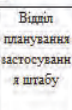 & 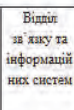 & 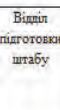 & 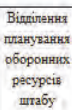 \\
\hline \multirow{2}{*}{ коеф. } & & & & & & & & & \\
\hline & 0 & 0 & 0,54 & 0,89 & 0,81 & 0,7 & 0,42 & 0,64 & 0 \\
\hline 0,026301 & 0,8 & 0 & 0,45 & 0 & 0,77 & 0,4 & 0 & 0,45 & 0 \\
\hline \multirow{2}{*}{0,022747} & 0,1 & 0,1 & 0,54 & 0 & 0 & 0 & 0,37 & 0,37 & 0 \\
\hline & 0 & 0 & 044 & 0 & 0 & 0 & 07 & 0 & \\
\hline \multirow{3}{*}{$\begin{array}{l}0,022747 \\
0,020614\end{array}$} & & & & & & & & & \\
\hline & 0 & 0 & 0,76 & 0,7 & 0 & 0 & 0,64 & 0 & 0 \\
\hline & 0,23 & 0,21 & 0,82 & 0,82 & 0,2 & 0,82 & 0,64 & 0,82 & 0,82 \\
\hline \multirow{2}{*}{0,024453} & 0,13 & 0,8 & 0,4 & 0,4 & 0,8 & 0,8 & 0,64 & 0,8 & 0,8 \\
\hline & 0,19 & 0,19 & 0,64 & 0,2 & 0,78 & 0,78 & 0,64 & 0,78 & 0,78 \\
\hline & 0,18 & 0,18 & 0,18 & 0,18 & 0,18 & 0,18 & 0,64 & 0,18 & 0,05 \\
\hline & 0.65 & 0,7 & 0.43 & 0.43 & 0.8 & 0,43 & 0.47 & 0.43 & 0.9 \\
\hline
\end{tabular}

Рис. 3. Варіант розрахунку

Джерело: розроблено авторами.

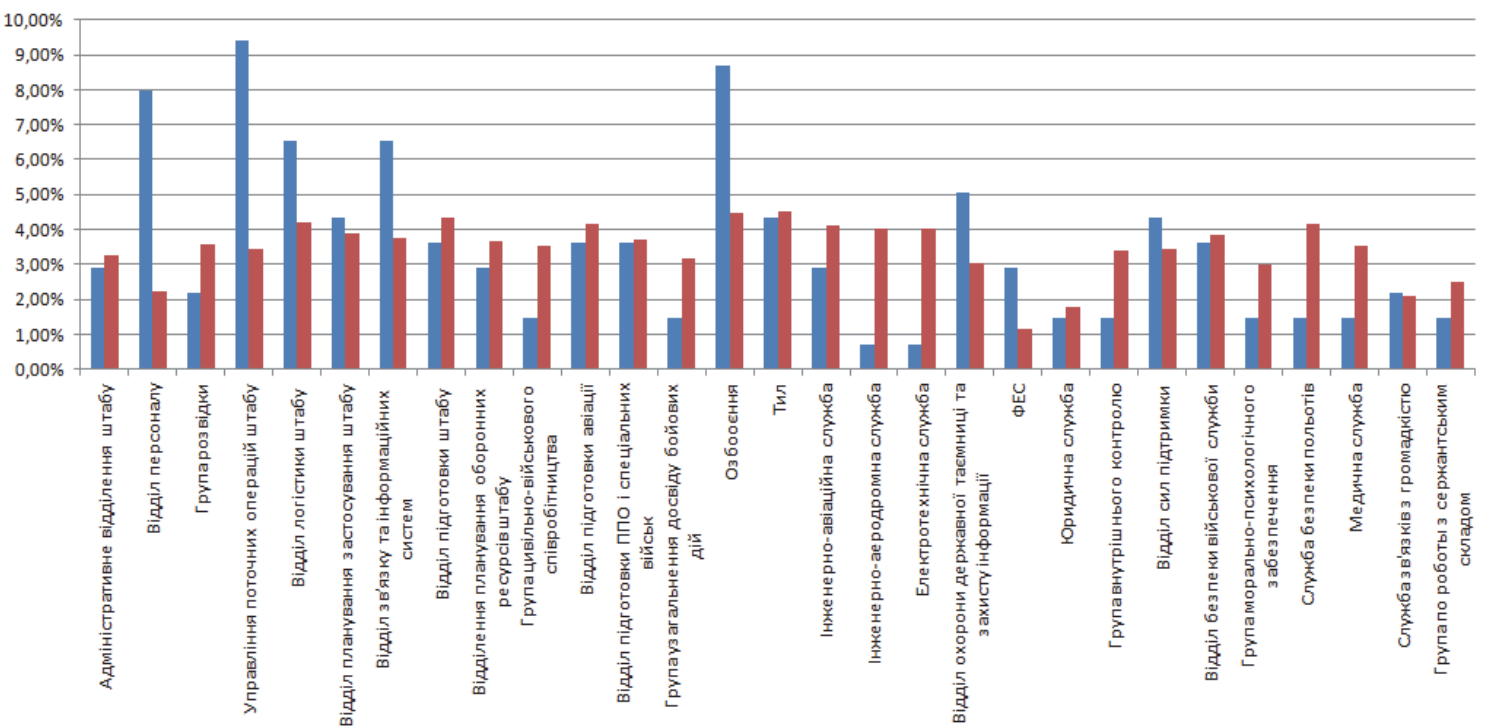

Рис. 4. Варіант графіку оцінювання військової організаційної структури за другим етапом методики Джерело: розроблено авторами.

Таблиця 2

Оцінювання органу військового управління за практичну роботу на пункті управління

\begin{tabular}{|c|c|}
\hline Оцінка & Характеристика оцінки \\
\hline $\begin{array}{c}\text { “Спроможний } \\
\text { виконувати завдання } \\
\text { за призначенням” }\end{array}$ & $\begin{array}{l}\text { Якщо система управління розгорнута та готова до виконання завдань за призна- } \\
\text { ченням, діяла злагоджено і організовано, посадові особи приймали доцільні рі- } \\
\text { шення, які відповідали умовам обстановки, що склалася, якісно та своєчасно } \\
\text { проводили заходи щодо управління військами (силами), при цьому були допу- } \\
\text { щені незначні помилки, які не вплинули на виконання поставлених завдань }\end{array}$ \\
\hline $\begin{array}{c}\text { “Обмежено } \\
\text { спроможний } \\
\text { виконувати завдання } \\
\text { за призначенням” }\end{array}$ & $\begin{array}{l}\text { Якщо система управління розгорнута, але недостатньо готова до виконання за- } \\
\text { вдань за призначенням, загалом виконала поставлені завдання, посадові особи } \\
\text { приймали доцільні рішення, які не повністю відповідали умовам обстановки, що } \\
\text { склалася, заходи щодо управління військами (силами) виконувалися недостатньо } \\
\text { якісно та були допущені незначні помилки, при цьому були допущені незначні } \\
\text { помилки, які призвели до перевищення строків їх виконання до } 30 \%\end{array}$ \\
\hline $\begin{array}{c}\text { “Неспроможний } \\
\text { виконувати завдання } \\
\text { за призначенням” }\end{array}$ & $\begin{array}{l}\text { Якщо система управління не розгорнута або не готова до виконання завдань за } \\
\text { призначенням, прийняті рішення не відповідали умовам обстановки, що склала- } \\
\text { ся, заходи управління військами (силами) виконувалися неякісно, з грубим по- } \\
\text { рушенням, які привели до перевищення строків їх виконання більше, ніж на } 30 \% \\
\text { або взагалі управління військами було втрачено }\end{array}$ \\
\hline
\end{tabular}

Джерело: розроблено авторами. 


\section{Висновки}

Таким чином, в статті визначено, що проектування раціональних організаційно-штатних структур неможливе без проведення якісного функціонального обстеження.

В статті розроблено трьохетапну методику функціонального обстеження військової організаційної структури, яка дозволяє оцінити відповідність організаційно-штатної структури військової організаційної структури покладеним на неї завданням.

Напрямом подальших досліджень $є$ розроблення методичного апарату проектування раціональних організаційно-штатних структур за результатами проведення функціонального обстеження.

\section{Список літератури}

1. Смірнов Є.Б. Принцип системності в воєнному мистецтві. Ведення збройної боротьби у повітрі / Є.Б. Смірнов // Збірник наукових праць Харківського національного університету Повітряних Сил. - 2016. - № 4(49). - С. 18-22.

2. Малюга В.Г. Методичний підхід до проектування структури органів управління Повітряних Сил / В.Г. Малюга // Системи озброєння і військова техніка. - 2016. - № 4(48). - С. 123-126.

3. Коваль В.В. Можливі підходи до визначення раціонального варіанту складної системи військового призначення / В.В. Коваль, В.В. Ткачов, О.М. Жарик // Наука і техніка Повітряних Сил Збройних Сил України. - 2011. - № 2(6). C. 7-9.

4. Воробйов Г.П. Методичні підходи до обгрунтування перспективної структури системи управління військами (силами) / Г.П. Воробйов // Збірник наукових праць ОНДІ ЗС. -2006 . - № 3(5). - С. 3-15.

5. Малюга В.Г.Удосконалена сукупність показників якості для обгрунтування структури органів управління системи управління Повітряних Сил / В.Г. Малюга, А.В. Тристан, В.Г. Паталаха // Сучасні інформаційні технології у сфері безпеки та оборони. - 2016. - № 3(27). - С. 72-77.

6. Гаценко С.С. Аналіз існуючого стану автоматизованих систем управління військами Збройних Сил України та шляхи їх удосконалення / С.С. Гаценко // Збірник наукових праць Центру воєнно-стратегічних досліджень Національного університету оборони України ім. І. Черняховського. - 2015. - №2 - С. 85-90.

7. Малюга В.Г. Вплив інформаційного забезпечення на прийняття управлінських рішень / В.Г. Малюга // Збірник наукових праць Харківського університету Повітряних Сил. - 2006. - № 6(12). - С. 77-79.

8. Парабеллум А.В. Трансформация бизнеса. Построение эффективной компании / А.В. Парабеллум, Н.К. Мрочковский. - СПб.: Питер, 2013. - 224 с.

9. Радкявичюс Дарюс. Бог, квантовая физика, организационная структура и стиль управления / Дарюс Радкявичюс, Томас Станюлис. - М.: Companion Group, 2010. - 240 c.

10. Приходько Д.И. Организационные структуры успешных корпораций / Д.И. Приходько. - М.: Инфотропик Медиа, 2012. $-266 \mathrm{c}$.

11. Методика розподілу оборонного бюджету України між складовими сил оборони з урахуванням показників потреб та пріоритетності завдань цих складових на плановий рік / О.М. Семененко, Р.В. Бойко, О.Г. Водчиць, С.П. Василенко, Г.Г. Зубрицька, О.І. Кремешний // Наука і техніка Повітряних Сил Збройних Сил України. - 2017. - № 4(29). - C. 123-131. https://doi.org/10.30748/nitps.2017.29.17.

12. Доктрина з організації оцінювання (сертифікації) у Збройних Силах України (ВКП 7-00(03).01).

13. Наказ ГШ ЗС України від 02.01.20 №1 "Про затвердження Інструкції з організації підготовки та проведення перевірок у Збройних Силах України”.

\section{Відомості про авторів:}

\section{Дроздов Сергій Семенович}

кандидат військових наук

Командувач Повітряних Сил

Збройних Сил України,

Вінниця, Україна

https://orcid.org/0000-0001-9704-4023

\author{
Псвцов Геннадій Володимирович \\ доктор технічних наук професор \\ заступник начальника Харківського національного \\ університету Повітряних Сил ім. І. Кожедуба \\ 3 наукової роботи, \\ Харків, Україна \\ https://orcid.org/0000-0002-0426-6768
}

\section{Тристан Андрій Вікторович}

доктор технічних наук старший науковий співробітник начальник науково-дослідного управління

Харківського національного університету

Повітряних Сил ім. І. Кожедуба,

Харків, Україна

https://orcid.org/0000-0002-2137-5712

\section{Information about the authors:}

\author{
Serhii Drozdov \\ Candidate of Military Sciences \\ Commander of the Air Force \\ of the Armed Forces of Ukraine, \\ Vinnytsia, Ukraine \\ https://orcid.org/0000-0001-9704-4023
}

\author{
Hennadii Pievtsov \\ Doctor of Technical Sciences Professor \\ Deputy Chief of Ivan Kozhedub Kharkiv National \\ Air Force University \\ in Science, \\ Kharkiv, Ukraine \\ https://orcid.org/0000-0002-0426-6768
}

\author{
Andrii Tristan \\ Doctor of Technical Sciences Senior Research \\ Chief of Scientific Research Management \\ of Ivan Kozhedub Kharkiv National \\ Air Force University, \\ Kharkiv, Ukraine \\ https://orcid.org/0000-0002-2137-5712
}




\title{
МЕТОДИКА ПРОВЕДЕНИЯ ФУНКЦИОНАЛЬНОГО ОБСЛЕДОВАНИЯ ВОЕННОЙ ОРГАНИЗАЦИОННОЙ СТРУКТУРЫ
}

\author{
С.С. Дроздов, В. Певцов, А.В. Тристан
}

Специфические факторы деятельности Воздушных Сил Вооруженных Сил Украины требуют поиска новых подходов к проектированию рациональной организационно-итатной структуры. Показано, что при разработке принципов и методик проектирования наиболее важным является установление порядка распределения задач между структурными составляющими, их вклада в достижение целей организации, а также соответствие штатной численности поставленным задачам (функциям). Предложен методический аппарат, который позволяет осуществить научное обоснование основных направлений как совершенствования систем управления, так и оптимизации военных организационных структур в иелом.

Ключевые слова: военная организационная структура, организационно-цтатная структура, Воздушные Силь Вооруженных Сил Украины, функииональное обследование.

\section{METHODOLOGY OF CONDUCTING FUNCTIONAL INSPECTION MILITARY ORGANIZATIONAL STRUCTURE}

\author{
S. Drozdov, H. Pievtsov, A. Tristan
}

It is defined in the article that the functional inspection of the military organizational structure is an important stage in the design of rational organizational and staffing structure. It is noted that when developing the principles and methods of designing organizational and staffing structures, it is important to move away from the idea of structure as fixed set of bodies corresponding to each specialized management function. Organizational and staffing structure is multifaceted concept. It primarily includes the system of goals and their distribution between different units, as the mechanism of activity should be focused on achieving goals. This also includes the composition of units that are linked by certain relations: the distribution of tasks and functions at all levels of government, the distribution of responsibilities, powers and rights in the organization, which reflects the relationship between centralization and decentralization of management. Important elements of the management structure are communications, information flows and document flow in the organization. Finally, the organizational and staffing structure is the behavioral system, it is people and their groups who constantly enter into various relationships to solve common problems. Such variety of the organizational mechanism is incompatible with the use of unambiguous methods - formal or informal. That is why it is necessary to proceed from combination of scientific methods and principles of formation of structures (system approach, program-target management, organizational modeling) with expert-analytical work, study of domestic and foreign experience, close interaction of scientists and those who will practically implement and use the designed organizational mechanism. The methodology of designing structures should be based on clear formulation of the goals of the organization. The issue of conducting a functional survey to implement the tasks of transformation and the formation of rational organizational and staffing structures is relevant for various areas of scientific, industrial, organizational activities. In the conditions of transformation of the Armed Forces of Ukraine, adaptation of their management system to NATO management systems, the task of conducting functional inspection of military organizational structures to determine the distribution of tasks between structural units, assessing the contribution of structural units in achieving organizational goals, compliance with staffing. Specific factors of activity of the Air Force of the Armed Forces of Ukraine, such as the organization of combat duty, command and control of troops during operations (combat operations) require the search for a new methodological apparatus that will assess the structural units of the military organizational structure and for specific tasks (functions). This methodological apparatus is necessary for the scientific substantiation of ways to both improve the management system and optimize military organizational structures in general.

Keywords: military organizational structure, organizational and staffing structure, Air Force, functional inspection. 